Jpn. J. Hosp. Pharm.

21 (4) $335-346(1995)^{\vdash}$

\title{
アンプル注射剤の識別性に関する考察
}

友藤昭夫*, 増田真一郎, 境 健司, 森田修之

倉敷中央病院薬剤部

\section{A Consideration of the Discriminative Factors of Ampules Used for Injection}

\author{
Akio Tomofuji*, Shinichiro Masuda, Kenji Sakai and Shushi Morita \\ Pharmaceutical Division, Kurashiki Central Hospital $\dagger$
}

(Received July 27, 1994 )

The discriminative factors of ampules utilized for injection were investigated statistically by quanti fication theory type $\mathbb{I}$, using the data collected from to administration of 216 ampules. A criterion variable was taken to be the answer given from 10 pharmacists to the question as to whether or not an ampule was easily discriminating, and the explanatory variables were taken as the categorical data regarding 10 items characterizing the ampules, such as the material.

The most significant factor was found to be the method of printing, followed by the number of colors in the printing and the physical properties of contents. The conclusion this study produced was that for discriminative improvement of ampules employed for injection, it was important that printing be done on a paper label, to increase the number of colors in the printing, and to design the label so that the product name can be easily read.

Keywords_ ampule for injection, discriminative factor, multivariate analysis, quantification theory type $\mathbb{I}$, discriminant analysis

錠剤やカプセル剂の識別性は，それらを取り扱 う医療従事者のみならず服用する患者にとっても 極めて重要なことである.そのためメーカー側 も，製剤本体や包装にかなりの工夫を施し識別性 の向上に努めている ${ }^{1,2)}$. しかし，注射剤では，自 己注射などの特別な場合を除いて，それを扱う者 が医療従事者に限られるためか，その識別性につ いてはあまり注意が払われていないように思われ る.

近年, 病院薬剂師が注射剂を個別に取り扱ら機 会が増えてきている．薬剤管理指導に伴ら処方せ

$\dagger$ 倉敷市美和 1-1-1；1-1-1，Miwa, Kurashiki, 710 Japan
んによる注射剤の交付, 病棟等における注射剤の 混合調製などの業務上の過誤防止のためにも，注 射剂の識別性の向上が強く求められている32.

そこで著者らは，注射剤の中でもバイアル注射 剂に比べ識別性が劣ると思われるアンプル注射剂 について，その識別性の良否を決定する因子を検 討するとともに各因子の重要性を定量的に評価す ることを目的として本研究を行った。

\section{調查と解析}

\section{1. 調查対象のアンプル注射削}

本院採用のアンプル注射剤のうち， $50 \mathrm{ml}$ 以下 の容器に収められている 216 品目を調査の対象と 
した.

\section{2. 識別性良否の官能検査}

本院の薬剤師の中から, 注射剂を取り扱ら機会: の多い者10名を選択し（経験 8 力月〜 7 年 8 力 月), 一人一人に各アンプルの識別性の良・不良を 即時回答させた。 以下，この官能検査の回答者を パネルとする。

\section{3. 識別性に影響する項目の選定と調査}

アンプル注射剂の識別性に影響すると思われる 項目として, 以下の10項目を選定した.

1） アンプルの材質

2) アンプル材質の色

3） アンプルの容積

4）アンプル内容物の性状

5）アンプル内容物の色

6）表示のための印刷方式

7) 印刷色数

8）容器の軸に対する印字の方向

9）識別マーク（カラーリングなど）の有無

10）定位置での識別の可否（定位置から表示が 一読できるかどらか)

そして，各項目について全てのアンプルを調查 した.

\section{4. 解析方法}

アンプルの識別性に上記の項目がどのように影 響するかを検討するために多変量解析の手法を用 いた．基準変数となる識別性については，「良」 と回答したものを 1 ，「不良」を 2 とカテゴリー 化した．付表 1 亿各パネルの回答結果を示す. 説 明変数となる項目の中で量的データであるアンプ ルの容積および印刷色数は，それぞれ $1 \sim 5$ およ び $1 \sim 4$ の順序尺度に変換した. 他の 8 個の項目 はいずれも名義尺度であるので, 各々 2 個から 4 個のカテゴリーを設けた. Table 1 に各变数のカ テゴリー区分を，また付表 2 に各アンプルのカテ ゴリーデータを示す。

質的データに変換した基準変数と説明変数に数 量化理論第 2 類を適用し解析した. 解析には, 多 变量解析ハンドブック・ソフト「HALBAU 」4) お よび医学統計解析ソフト「NAP $」^{5)}$ を併用した。

\section{結果と考察}

\section{1. 官能検査}

10名のパネルによるアンプル識別性の回答結果 を Fig. 1 に示す：横軸は10名のうち識別性不良 と答えた人数を，綎軸はアンプル注射剤の数を表 わしている。 216 品目のちち7.9品目 (36.6\%) は

Table 1. 变数のカテゴリー化

\begin{tabular}{|c|c|c|c|c|c|c|}
\hline カ & $\overline{テ コ リ ー ~}$ & 1 & 2 & 3 & 4 & 5 \\
\hline 基隻 & アンプルの識別性 & 良 & 不良 & & & \\
\hline \multirow{4}{*}{ 説 } & アンプル材質 & ガラス & プラスチック & & & \\
\hline & フンプル材質の色 & 透明 & 褐色 & & & \\
\hline & フンフフル容積 & $1 \mathrm{ml}$ & $2 \mathrm{ml}$ & $3 \sim 5 \mathrm{ml}$ & $6 \sim 10 \mathrm{ml}$ & $11 \mathrm{~m} /$ 以上 \\
\hline & アンプル内容物性状 & 液 & 凍結乾燥 & 粉末 & & \\
\hline \multirow[t]{2}{*}{ 明 } & フンプ 凡内容物の色 & 無色or白色 & 着色 & & & \\
\hline & 印刷方式. & 直接 & $\begin{array}{l}\text { フイル } \\
\text { (下地無) }\end{array}$ & $\begin{array}{l}\text { フイルム* } \\
\text { (下地有) }\end{array}$ & 紙ラベル & \\
\hline 変 & 印刷色数 & 1 色 & 2 色 & 3色 & 4 色以上 & \\
\hline \multirow[t]{3}{*}{ 数 } & $\begin{array}{c}\text { 印蓉栄向軸に対する } \\
\end{array}$ & 垂直 & $\begin{array}{c}\text { 平行 } \\
\text { (下から上) }\end{array}$ & $\begin{array}{c}\text { 平行 } \\
\text { (上から下) }\end{array}$ & & \\
\hline & 識別マーク & 有 & 無 & & & \\
\hline & 定位置での識別 & 可 & 不可 & & $\cdots$ & \\
\hline
\end{tabular}

*下地に直接印刷されている場合を含む 


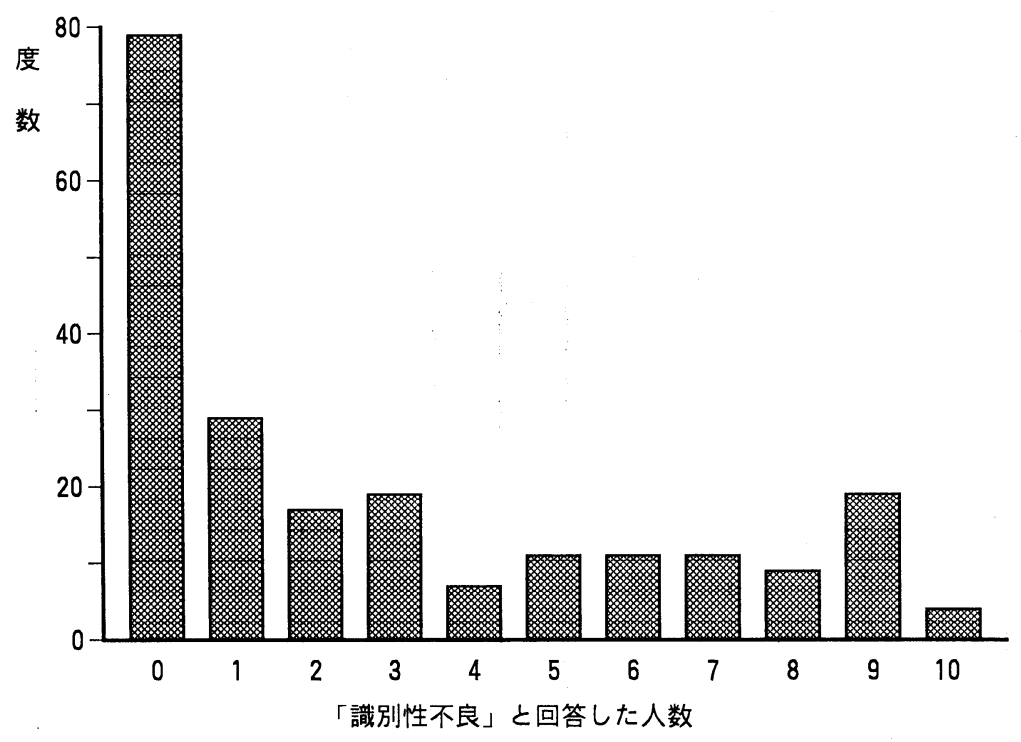

Fig. 1. 官能検查結果 (パネル : 10名, 注射剂サンプル数 : 216)

誰も不䬶と答えていない。また，4品目について は10名全員が不良と答えている．他のアンプルに ついては，1名から9名が不良と答えているが，

Fig. 1 のように広く分布しており，パネル間の感 受性に大きな相違が認められる.

そこで，パネルの経験年数とパネルが識別性不 良と回签したアンプル数（付表 1 ）との相関の有 無を検討した. 再者の単純相関係数は $0.197(\mathrm{t}=$ $0.569: \mathrm{P}=0.585$ ）であったことから，パネル間 の感受性の相違は経験度によるとはいえないと考 兄られた。

\section{2. 各カテゴリーの重み係数}

まず，パネル一人一人について，数量化 2 類に より各カテゴリーの重み係数を算出した．Fig. 2 は, 得られた各人の重み係数の平均值と標準偏差 を各説明変数・各カテゴリ一毎に示している。

本計算に打いては，カテゴリ一の重み係数が負 であればあるほど識別性は良好，正であればある ほど識別性は不良であることを示す。なた，ある 説明変数がパネルの識別性の判断にどの程度寄与 しているかは, カテゴリーの重久係数の平均值の 範囲の大きさで推測できる。例光ば，アンプル材 質では, プラスチックの平均值十0.12 とガラスの 平均值一 0.01 との差 0.13 がその範囲であり, アン
プル内容物性状では，最大值は液の +0.05 , 最小 值は粉末の一 0.58 であるから範囲は 0.63 となる。 したがって，両者を比較した場合，識別性への寄 与はアンプル内容物性状の方が大きいといえる.

Fig. 2 から明らかなように, 印刷方式は範囲が 最大，すなわち，識別性への寄与が最も大きい。 そして，製品名などを容器に直接印刷したものの 識別性が最も悪く，紙ラベルに印刷したものが最 も良く，また，透明フィルムに印刷されたもので は下地があるものの方が無いものより良い，とい ら結果が得られた。これは, 直接印刷や透明フィ ルム印刷ではアンプル内容物やアンプルの裏側の 背景が透けて見光，印刷の文字が判読しにくくな るためと推測される.

識別性への寄与が次に大きいものはアンプル内 容物性状であり, 凍結乾燥や粉末状のものが液状 のものより識別性が良いと感じている．アンプル 内容物が液状のものでは, 液が動いた場合に光を 反射し，そのために識別性が悪くなったのではな いかと考えられる。

印刷色数も重要であり，色の数が多いほど識別 性は向上している. 印刷色数の多さは, 直接的な 文字の判読といらょりも，印刷全体のイメージの 差別化に役立っているのではないかと考光られ 


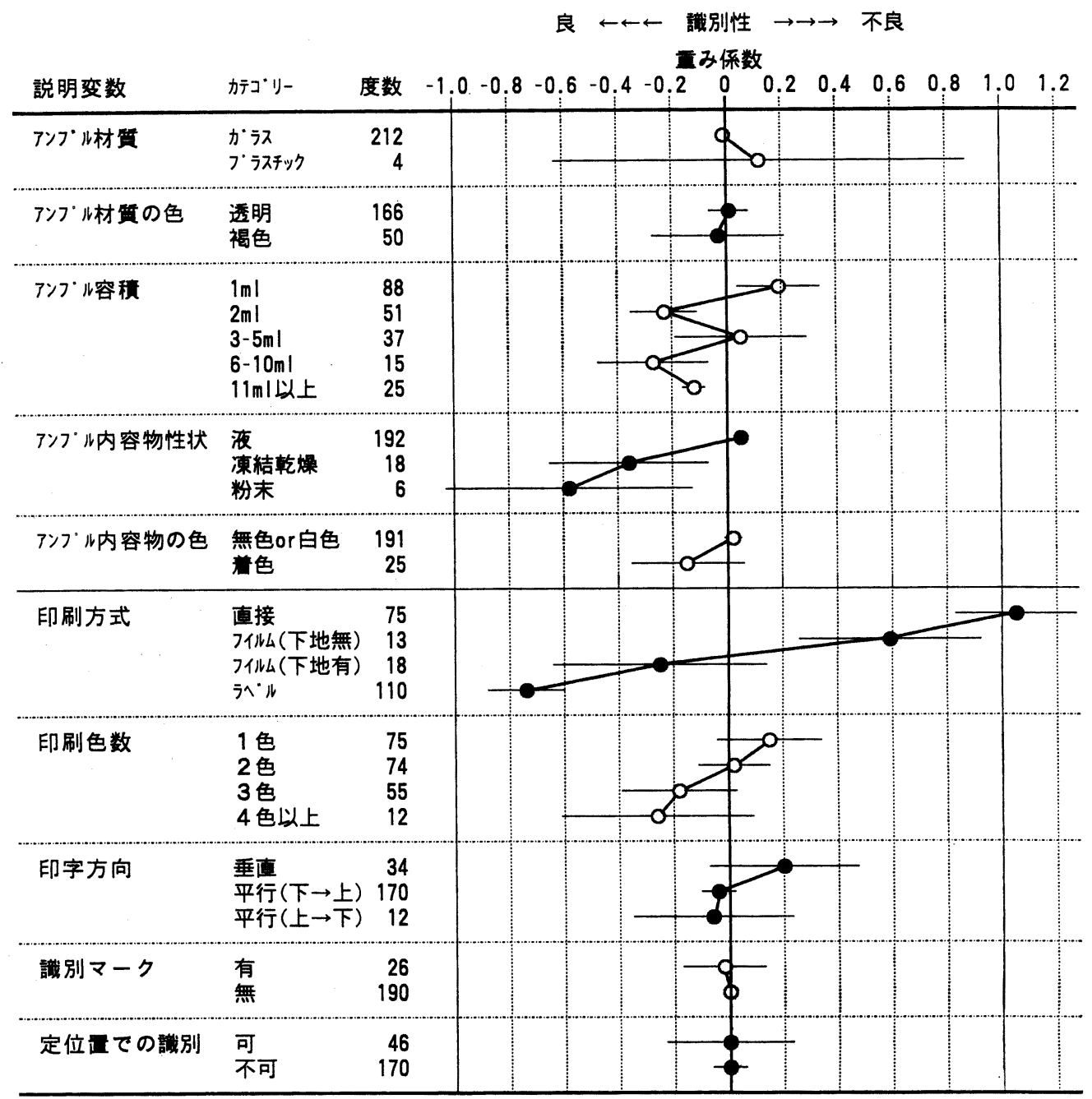

Fig. 2. 各カテゴリーの重み係数

る.

アンプル容積も識別性への寄与が認められる. $1 \mathrm{ml}$ の容器の識別性が最も悪く, 容積が大きくな るにつれて良好となるよらである．アンプル容積 が大きいほど，印刷の文字も大きくなり，それが 識別性の向上に寄与しているのではないかと考え られる。しかし， $2 \mathrm{ml}$ と 3〜 $5 \mathrm{ml}, 6 \sim 10 \mathrm{ml}$ と 11 $\mathrm{ml}$ 以上で逆転現象が見られる. カテゴリー数を 多くとりすぎたため，あるいは他の項目との交互 作用によるため，などが考えられるが明確な理由 は定かではなく今後の検討課題と考えている.
印字方向の寄与はあまり大きくないが，容器の 軸に対し垂直な文字列は識別性を悪くするようで ある、垂直な文字列ではアンプルを大きく回転さ せなければ判読できない場合があることによると 考えられる.

一方, 重み係数の標準偏差が大きいものほど, そのカテゴリーが各々のパネルに与える影響度の 違いが大きいことを示す，例えば，プラスチック アンプルはあるパネルには悪いと感じさせるし， 他のパネルにはその逆である. アンプル内容物が 粉末のものは識別性が良好といえるが，パネルの 
感じ方には大きな相違がある。

以上のことから，アンプル注射剤の識別性の良 否に対する各パネルの感じ方は拈拈むね同様であ るものの, アンプル材質・その容積・印字方向な どには個人差が見受けられ，また，アンプル材質 の色・識別マークの有無・定位置から表示が一読 できるかどうか（定位置での識別）は識別性にほ とんど影響しないと考えられた。 そこで著者ら は, 着目した10項目の中でアンプルの識別性に影 響すると確信していえる項目を探索することを目 的として, 判別分析の手法を用いて検討した.

\section{3. 判別分析}

何パーセント以上のパネルが不良と答えたもの を真に不良であるとするか，このパーセントの境 界值を「不良判定水準」と呼ぶこととする.

Fig. 3 は, 10名のパネル中 6 名以上が識別性不 良であると回答したアンプルが真に不良であると 仮定したとき，すなわち，不良判定水準を $60 \%$ と 仮定したときの「不良群」をグループ 2 , この群
に入らない「不良とは言えない群」をグループ 1 として判別分析を行った結果である.

上側に示した判別得点の分布は，10個の説明変 数の全てを含めて得られた結果である. 正判別率 は全体で $83.8 \%$ であり，2 群の判別は良好であ る.しかし、この分析には統計学的には無意味な 変数も含んでいる，そこで， F 検定による変数減 少法により有意な变数を選択した. 变数削除の判 断の指標としての $\mathrm{F}$ 值 $=2.0$ と設定して行った. その結果, 5 個の変数 (アンプル容績, アンプル 内容物性状, 印刷方式, 印刷色数, 印字方向) が 選択され，このときの判別得点が下側の分布であ る. 変数選択前の分布との違いはほとんどなく， 正判別率は $83.3 \%$ であって選択前よりわずか 0.5 \%低いだけである。すなわち，不良判定水準 $60 \%$ においては，削除された 5 個の変数（アンプル材 質, アンプル材質の色, アンプル内容物の色, 識 別マーク，定位置での識別）の識別性への寄与は 無視できると考えられる.


Fig. 3. 不良判定水準60\%における判別得点分布 


\section{4. 不良判定の指標と影響因子}

不良判定水準の值によって判別分析の結果は異 なる。したがって：アンプルの識別性の良否を決 定する説明变数を確定するためには不良判定水準 をどこに置くかを決めなければならない。そこ で，著者らは，不良判定水準をパラメータとして 判別分析を行い, 正判別率, 正準相関係数 (R) および判別された 2 群の重心距離が最大となる パラメータ值を求め, これらの值を識別性に影響 する变数を決定するための指標とすることとし た。

Fig. 4 亿各パラメータ值に対する正判別率を示 す.いずれのパラメータ值に执いても，変数選択 前と選択後の正判別率には，グループ 1 （不良と は言えない群), グループ 2 (不良群), 全体（グ ループ 1＋2）ともほとんど差が認められない。 そして，パラメータ值が30\%に扣いて全体の正判 別率は $89.4 \%$ と最大であり，また，パラメータ值 が30\%拈よび $40 \%$ のさ，グループ 1，2 とも平 均的に良く判別されていることがわかる.

Table 2 に，各パラメータ值に打いて，有意と 判定された変数すなわち選択された变数の偏相関



Fig. 4. 正 判 別 率
係数，正準相関係数および判別分析における $2 つ$ のグループの重心の距離を示す．偏相関係数が大 きいほどその変数が 2 群の判別に大きく寄与して いるといえる，また，正準相関係数が大きいほ ど，そして 2 群の重心距離が大きいほど，2 群の 判別は良好であるといえる.

印刷方式はすべてのパラメータ值において選択 され，偏相関係数も $0.346 \sim 0.773$ 之選択された 変数の中で最も大きい.すなわち, アンプルの識 別性に対する支配的因子といえる. 印刷色数は偏 相関係数 $0.116 〜 0.202$ とあまり大きくはないが， いずれのパラメータ值に扎いても選択されてい る.

パラメータ值30\%に执いては，最も少ない説明 変数数 ( 3 個) で, 正判別率 $=89.4 \%$ (Fig. 4), $\mathrm{R}=0.802$ といずれも最大值が得られ，また， 2 群の 重心距離=1.624 で 2 番目に大きい. 一方, パラメータ值40\%においては， 2 群の重心距離= 1.694 と最大であり，また， $\mathrm{R}=0.799$, 正判別率 $=88.4 \%$ でともに 2 番目に大きいが，説明変数 5 個を要している，パラメータ值10\%，20\%および $50 \%$ 80\%では, 説明変数 3 個またはとれ以上を 
Table 2. 変数選択の結果と偏相関係数

\begin{tabular}{|c|c|c|c|c|c|c|c|c|}
\hline \multicolumn{2}{|c|}{ 不良判定水準（\%） } & 10 & 20 & 30 & 40 & 50 & 60 & 80 \\
\hline \multirow{3}{*}{ 説 } & フンプル材質 & 0.143 & & & & & & \\
\hline & アンプル材翼の色 & & & & & & & \\
\hline & アンプル容皘 & 0.151 & & & 0.189 & 0.269 & 0.265 & 0.250 \\
\hline \multirow{2}{*}{ 明 } & アンプル内容物性状 & 0.118 & 0.180 & 0.166 & 0.348 & 0.281 & 0.214 & \\
\hline & フンプル内容物の色 & & & & 0.121 & & & \\
\hline \multirow{2}{*}{ 変 } & 印刷方式 & 0.439 & 0.694 & 0.773 & 0.721 & 0.605 & 0.520 & 0.346 \\
\hline & 印刷色数 & 0.202 & 0.177 & 0.184 & 0.196 & 0.193 & 0.118 & 0.116 \\
\hline \multirow{3}{*}{ 数 } & 印字方向 & 0.148 & & & & & 0.136 & \\
\hline & 識別マーク & 0.120 & & & & & & \\
\hline & 定位置での識別 & 0.123 & & & & & & \\
\hline \multicolumn{2}{|c|}{ 選択された説明変数数 } & 8 & 3 & 3 & 5 & 4 & 5 & 3 \\
\hline \multicolumn{2}{|c|}{ 正準相関係数(R) } & 0.663 & 0.747 & 0.802 & 0.799 & 0.744 & 0.677 & 0.514 \\
\hline \multicolumn{2}{|c|}{2 群の重心距離 } & 1.361 & 1.493 & 1.624 & 1.694 & 1.622 & 1.563 & 1.447 \\
\hline
\end{tabular}

要しているが， Rおよび 2 群の重心距離ともパラ メータ值30\%のそれらより小さい.

これらのことから，著者らは，パネルの30\%以 上が識別性不良と回答したアンプルを真に不良で あると判定することとした，そして，識別性の良 否の判断に影響する支配的因子は，印刷方式，印 刷色数およびアンプル内容物性状であり，その中 で印刷方式が最も重要であると結論づけた.

\section{5. 誤判別の原因}

Fig. 5 に不良判定水準30\%に打汀る変数選択
後の判別得点の分布を示す. 識別性が良・不良 2 群の分離は極めて良好である. しかし, 誤って判 別されたものが全体で10.6\%あることから，誤判 別された 23 ンプルについて，その原因を検討し てみた。 その結果, 製品名の表示方法が極めて重 要であることが判明した。たとえば，ラベル印刷 で印刷色数が多くても，製品名が一見して判読で きないようなデザインではパネルの多くが不良と 回答している，逆に，アンプルに直接印刷されか つ単色であっても, 製品名が鮮明な色調で判読し

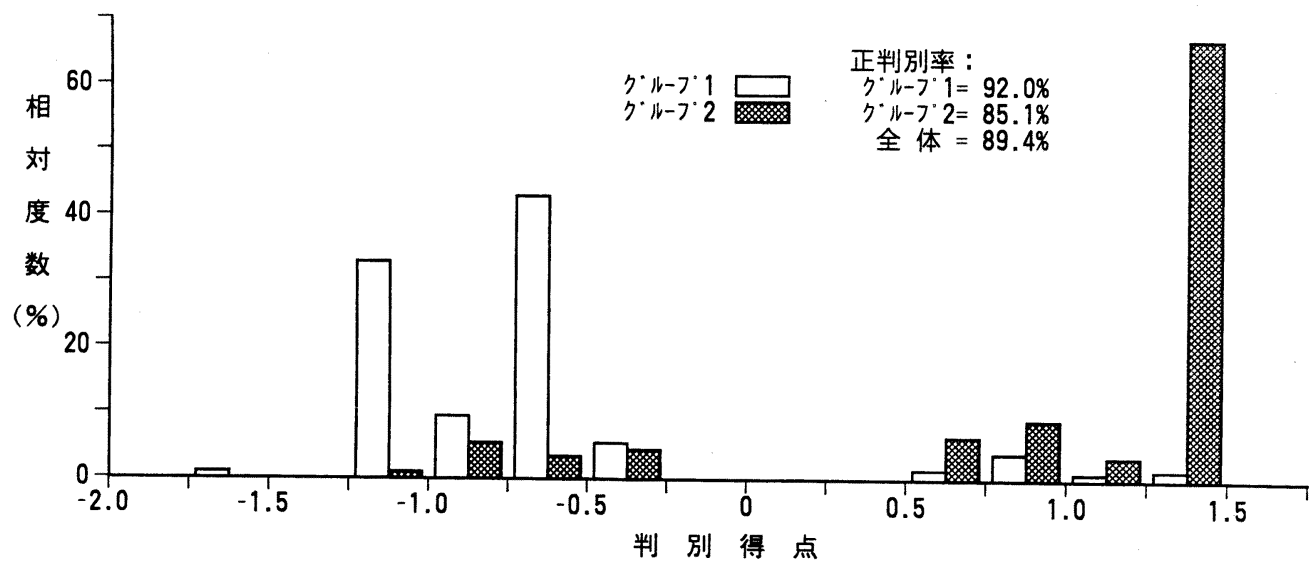

Fig. 5. 不良判定水準30\%に拉ける変数選択後の判別得点分布 
やすいデザインであれば不良とは回答していな い.

前述のように, アンプル注射剂の識別性に影響 する最大の因子は印刷方式であり，次いで印刷色 数およびアンプル内容物の性状であった。 このう ち，アンプル内容物の性状は変更できない因子で あるので, 残る印刷方式および印刷色数への配虑 が極めて重要であると言える.そして, 判別分析 に拈ける誤判別の主な原因がラベルのデザインで あると推察された。

以上のことから，アンプル注射剂の識別性の向 上のためには, 製品名等を紙ラベルに印刷し, そ の印刷色数を多くし,さらに製品名が判読しやす
いデザインを工夫することが肝要であると考えら れた。

\section{引用文献}

1) 栢野正則, 月刊薬事, 31, 1953-1963 (1989).

2) 森田修之, 月刊薬事, 31, 1965-1972 (1989).

3）境 健司, 增田真一郎, 友藤昭夫, 森田修之, 第 31回日本薬学会中国四国支部大会講演 要旨集, 115 (1992).

4）佐藤俊哉, “多変量解析ハンドブック”, 柳井晴 夫, 高木廣文編, 現代数学社, 京都, $1989, \mathrm{p}$. 126-159.

5) 青木繁伸, “医学統計解析リフフレンスマニュア ル”, 医学畫院, 東京, 1989, p.304-313. 
付表 1. 各パネルの回答結果 $(1:$ 良, 2 : 不良)

(1)

\begin{tabular}{|c|c|c|c|c|c|c|c|c|c|c|c|}
\hline 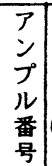 & $\begin{array}{l}\mathrm{I} \\
0.70 \\
42\end{array}$ & & $\begin{array}{r}11 \\
2.7 \\
29\end{array}$ & $\begin{array}{l}\{ \\
\mathrm{N} \\
1.71 \\
541\end{array}$ & $\begin{array}{l}\text { 上段段 } \\
\text { 下段 } \\
\mathrm{V} \\
73 \\
14\end{array}$ & $\begin{array}{l}: 1 \\
\vdots \\
\vdots \\
\vdots \\
\text { 経 } \\
7 \\
76\end{array}$ & 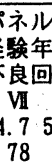 & & & $\begin{array}{r}X \\
7.7 \\
55\end{array}$ & \begin{tabular}{|l} 
不 \\
良 \\
签 \\
数
\end{tabular} \\
\hline 1 & 2 & 2 & 1 & 2 & 2 & 2 & 2 & 2 & 1 & 2 & 8 \\
\hline 2 & 1 & & 1 & & 2 & 1 & & & i & & \\
\hline 3 & $i$ & 1 & 1 & 2 & & i: & $i$ & 1 & 1 & & \\
\hline & 1 & 1 & 1 & 1 & 2 & 1: & 1 & 1 & 1 & 1 & 1 \\
\hline & 1 & 2 & 2 & 2 & 2 & 2 & 2 & 2 & 2 & 2 & 9 \\
\hline 6 & 2 & 2 & 2 & 2 & 2 & 2 & 2 & 2 & $i$ & & 9 \\
\hline 7 & 1 & 1 & 1 & 1 & 1 & 1: & 1 & 1 & 1 & 1 & $\emptyset$ \\
\hline & 1 & & 1 & 1 & 1 & 1: & $1:$ & & & & \\
\hline & 1 & & 1 & 1 & 1 & 1 & $1^{\prime}$ & 1 & 1 & & \\
\hline 10 & 1 & & 1 & 1 & 1 & 1 & 1 & 1 & 1 & 1 & $\emptyset$ \\
\hline 11 & & & 1 & 1 & 1 & 1 & 1 & 1 & 1 & 1 & \\
\hline 12 & 1 & & $i$ & $i$ & $i$ & $i$ & $i$ & 1 & 1 & $i$ & ע \\
\hline $\begin{array}{ll}13 \\
\end{array}$ & $i$ & 2 & $i$ & 1 & 2 & 2 & 2 & 2 & 2 & 2 & 7 \\
\hline 14 & $1:$ & 2 & 1 & 1 & 1 & 1 & 1. & 1 & 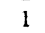 & 1 & 1 \\
\hline 15 & 1 & 1 & 1 & i & $i$ & $i$ & 1 & 1 & 1 & & $\emptyset$ \\
\hline 16 & 1 & 2 & 1 & 1 & 1 & 1 & 1 & 1 & 1 & 1 & \\
\hline 17 & 2 & 1 & 1 & 1 & 2 & 2 & 2 & 2 & & & 5 \\
\hline & 1 & 1 & 1 & 1 & 1 & 1 & 1 & 1 & 1 & 1 & $\emptyset$ \\
\hline & 1. & 1 & 1 & 1 & 1 & 2 & 2 & 1 & 1 & 1 & 2 \\
\hline $2 \theta$ & 1 & 1 & 1 & 1 & 1 & 2 & 2 & 1 & 1 & 1 & 2 \\
\hline 21 & 1 & & 1 & 2 & 2 & 1 & 2 & 1 & 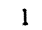 & 2 & 4 \\
\hline 22 & 1 & 2 & 1 & 2 & 2 & 2 & 2 & 2 & 2 & 2 & \\
\hline 23 & 1 & & 2 & 2 & 2 & 2 & 2 & 2 & 2 & 2 & 9 \\
\hline 24 & 1 & 2 & 2 & 2 & 2 & 2 & 2 & 2 & 1 & 2 & 8 \\
\hline 25 & 2 & 2 & 1 & 1 & 2 & 2 & 2 & 1 & $i$ & 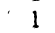 & 5 \\
\hline & 1 & & 1 & 1 & 1 & 1 & 1 & 1 & 1 & & $\emptyset$ \\
\hline & & 2 & 1 & 1 & 2 & 2 & 2 & i & & & \\
\hline & 1 & 1 & 1 & 1 & 1 & 1 & 1 & 1 & 1 & 1 & $\theta$ \\
\hline & 1 & 1 & 1 & 1 & 2 & 1 & 1 & 1 & 1 & 1 & \\
\hline $3 t$ & 1 & 1 & 1 & 1 & 2 & 1 & 2 & 2 & 2 & 2 & 5 \\
\hline 31 & 1 & 1 & 1 & 1 & 1 & 1 & 1 & 1 & 1 & 1 & $\theta$ \\
\hline 32 & 1 & 2 & 1 & 1 & 2 & 2 & 2 & 2 & 1 & 1 & \\
\hline 33 & & & 1 & & 2 & 2 & 1 & 2 & & 1 & \\
\hline 34 & & & 1 & & & 2 & 2 & 2 & & & \\
\hline & & & 2 & 2 & 2 & 2 & 2 & & 2 & & \\
\hline & 1 & 1 & 1 & 1 & $i$ & 1 & $i$ & 1 & & & o \\
\hline & & 2 & 1 & 2 & 2 & 2 & 2 & 2 & & & 9 \\
\hline 38 & 1 & 2 & 1 & 1 & 2 & 1 & 1 & 2 & 1 & 1 & 3 \\
\hline 39 & 2 & 2 & 2 & 2 & 2 & 2 & 2 & 2 & 2 & 2 & 10 \\
\hline 40 & 2 & 2 & 1 & 1 & 2 & 1 & 1 & 1 & 1 & 1 & 3 \\
\hline 41 & 1 & 1 & 1 & 2 & 1 & 1 & 1 & 2 & 1 & 1 & 2 \\
\hline 421 & 1 & & 1 & & & 1 & 1 & 1 & 1 & 1 & $\emptyset$ \\
\hline 43 & & & 1 & & & 1 & 1 & 1 & 1 & $i$ & Ø \\
\hline 44 & & & 1 & & & 1 & 1 & 1 & 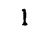 & & $\emptyset$ \\
\hline 45 & 2 & 2 & 1 & 2 & 2 & 2 & 2 & 2 & 2 & 2 & 9 \\
\hline 46 & 1 & $?$ & 1 & 1 & 2 &  & 1 & $i$ & & 1 & 2 \\
\hline 4 & 1 & 2 & 1 & 1 & 2 & 2 & 2 & 1 &  & 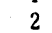 & 6 \\
\hline $4 \xi$ & 1 & 1 & 1 & 1 & 1 & 1 & 1 & 1 & & & $\emptyset$ \\
\hline $4 !$ & 2 & 2 & 1 & 2 & 2 & 2 & 2 & 2 & 2 & 2 & 9 \\
\hline & 1 & 1 & 1 & 2 & 2 & 1 & 2 & 2 & 2 & 2 & 6 \\
\hline & 1 & 1 & 1 & 1 & 1 & 1 & 1 & 1 & 1 & 1 & $\emptyset$ \\
\hline & 1 & 1 & 1 & 1 & 2 & 1 & 1 & 1 & 1 & 1 & 1 \\
\hline b. & & 1 & 1 & 1 & 1 & 1 & 1 & 1 & 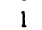 & $i$ & $\ddot{\emptyset}$ \\
\hline 5 & 1 & 2 & 1 & 1 & 1 & 1 & 1 & 1 & 1 & 1 & 1 \\
\hline 55 & 2 & 2 & & & 2 & 2 & 2 & 2 & 2 & $i$ & \\
\hline
\end{tabular}

\begin{tabular}{|c|c|c|c|c|c|c|c|c|c|c|c|}
\hline $\begin{array}{l}\text { ア } \\
\text { プ } \\
\text { ル } \\
\text { 番 } \\
\text { 号 }\end{array}$ & $\begin{array}{l}\text { パ } \\
\text { ネ } \\
\text { I }\end{array}$ & $\begin{array}{l}\text { パ } \\
\text { ネ } \\
\text { II }\end{array}$ & $\begin{array}{l}\text { パ } \\
\text { ネ } \\
\text { III }\end{array}$ & $\begin{array}{l}\text { パ } \\
\text { ネ } \\
\text { N }\end{array}$ & $\begin{array}{l}\text { パ } \\
\text { ネ } \\
\text { V }\end{array}$ & $\begin{array}{l}ハ 0 \\
\text { ネ } \\
\text { U }\end{array}$ & $\begin{array}{l}\text { パ } \\
\text { ル } \\
\text { 而 }\end{array}$ & $\begin{array}{l}\text { ハ } \\
\text { 政 }\end{array}$ & $\begin{array}{l}\text { パ } \\
\text { 耐 }\end{array}$ & $\begin{array}{l}\text { ハ } \\
\text { ネ } \\
\mathrm{X}\end{array}$ & $\begin{array}{l}\text { 不 } \\
\text { 良 } \\
\text { 回 } \\
\text { 答 } \\
\text { 数 }\end{array}$ \\
\hline 56 & 2 & 2 & 2 & 2 & 2 & 2 & 2 & 2 & 2 & 1 & $\sqrt{9}$ \\
\hline 57 & 1 & 1 & 1 & 1 & 1 & 1 & 1 & 1 & 1 & 1 & $\emptyset$ \\
\hline 58 & 2 & 2 & 1 & 2 & 2 & 2 & 2 & 2 & 2 & 2 & 9 \\
\hline 59 & 1 & 1 & 1 & 1 & 1 & 1 & 1 & 1 & 1 & 1 & 0 \\
\hline 60 & 2 & 2 & 1 & 1 & 2 & 2 & 2 & 2 & 1 & 1 & 6 \\
\hline 61 & 1 & 1 & 1 & 1 & 1 & 1 & 1 & 1 & 1 & 1 & 0 \\
\hline 62 & 1 & 1 & 1 & 1 & 2 & 1 & 2 & 1 & 1 & 1 & 2 \\
\hline 63 & 1 & 1 & 1 & 1 & 1 & 1 & 1 & 1 & 1 & 1 & 0 \\
\hline 64 & 1 & 1 & 1 & 1 & 1 & 1 & 1 & 1 & 1 & 1 & 0 \\
\hline 65 & 1 & 2 & 2 & 2 & 2 & 2 & 2 & 1 & 1 & 1 & 6 \\
\hline 66 & 1 & 1 & 1 & 1 & 2 & 2 & 2 & 1 & 1 & 1 & 3 \\
\hline 67 & 1 & 1 & 1 & 1 & 2 & 1 & 1 & 1 & 2 & 2 & 3 \\
\hline 68 & 1 & 1 & 1 & 1 & 2 & 1 & 1 & 1 & 2 & 2 & 3 \\
\hline 69 & 2 & 2 & 1 & 2 & 2 & 2 & 2 & 2 & 2 & 2 & 9 \\
\hline 70 & 1 & 1 & 1 & 1 & 1 & 1 & 1 & 1 & 1 & 1 & $\theta$ \\
\hline 71 & 1 & 1 & 1 & 1 & 1 & 2 & 1 & 1 & 1 & 1 & 1 \\
\hline 72 & 1 & 1 & 1 & 1 & 1 & 2. & 1 & 1 & 1 & 1 & 1 \\
\hline 73 & 1 & 2 & 1 & 1 & 2 & 1 & 2 & 1 & 1 & 1 & 3 \\
\hline 74 & 1 & 1 & I & 1 & 1 & 1 & 1 & 1 & 1 & 1 & 0 \\
\hline 75 & 1 & 1 & 1 & 1 & 1 & 1 & 1 & 1 & 1 & 1 & $\theta$ \\
\hline 76 & 1 & 1 & 1 & 1 & 1 & 1 & 1 & 1 & 1 & 1 & $\theta$ \\
\hline 77 & 1 & 1 & 1 & 1 & 1 & 1 & 1 & 1 & 1 & 1 & $\emptyset$ \\
\hline 78 & 1 & 1 & 1 & 1 & 1 & 1 & 1 & 1 & 1 & 1 & $\theta$ \\
\hline 79 & 1 & 1 & 1 & 1 & 1 & 1 & 1 & 1 & 1 & 1 & $\emptyset$ \\
\hline 80 & 1 & 1 & 1 & 1 & 1 & 1 & 1 & 1 & 1 & 1 & $\emptyset$ \\
\hline 81 & 1 & 1 & 1 & 1 & 2 & 2 & 2 & 2 & 1 & 2 & 5 \\
\hline 82 & 1 & 2 & 1 & 2 & 2 & 2 & 2 & 2 & 2 & 2 & 8 \\
\hline 83 & 1 & 1 & 1 & 1 & 1 & 1 & 1 & 1 & 1 & 1 & $\theta$ \\
\hline 84 & 1 & 1 & 1 & 1 & 1 & 1 & 1 & 1 & 1 & 1 & 0 \\
\hline 85 & 1 & 1 & 1 & 1 & 1 & 1 & 1 & 1 & 1 & 1 & 0 \\
\hline 86 & 1 & 1 & 1 & 1. & 2 & 2 & 1 & 1 & 1 & 1 & 2 \\
\hline 87 & 1 & 1 & 1 & 1 & 1 & 2 & 1 & 1 & 1 & 1 & 1 \\
\hline 88 & 1 & 1 & 1 & 1 & 2 & 1 & 1 & 1 & 1 & 1 & 1 \\
\hline 89 & 1 & 1 & 1 & 1 & 1 & 1 & 1 & 1 & $i$ & 1 & $\emptyset$ \\
\hline 90 & 1 & 1 & 1 & 1 & 1 & 1 & 1 & 1 & 1 & 1 & $\emptyset$ \\
\hline 91 & 2 & 2 & 2 & 2 & 2 & 1 & 2 & 2 & 2 & 2 & 9 \\
\hline 92 & 1 & 1 & 1 & 1 & 1 & 1 & 1 & 1 & 1 & 1 & $\theta$ \\
\hline 93 & 2 & 1 & 2 & 2 & 2 & 2 & 2 & 2 & 2 & 2 & 9 \\
\hline 94 & 1 & 1 & 1 & 1 & 1 & 1 & 1 & 1 & 1 & 1 & $\theta$ \\
\hline 95 & 1 & 1 & 1 & 1 & 1 & 1 & 1 & 1 & 1 & 1 & $\theta$ \\
\hline 96 & 1 & 1 & 1 & 1 & 1 & 1 & 1 & 1 & 1 & 1 & $\theta$ \\
\hline 97 & 1 & 1 & 1 & 1 & 2 & 1 & 1 & 1 & 1 & 1 & 1 \\
\hline 98 & 1 & 1 & 1 & 1 & 1 & 1 & 1 & 1 & 1 & 1 & $\emptyset$ \\
\hline 99 & 1 & 1 & 1 & 1 & 1 & 1 & 1 & 1 & 1 & 1 & 0 \\
\hline 100 & 1 & 2 & 1 & 1 & 2 & 1 & 2 & 1 & 1 & 1 & 3 \\
\hline 101 & 1 & 1 & 1 & 1 & 1 & 1 & 1 & 1 & 1 & 1 & $\emptyset$ \\
\hline 102 & 1 & 2 & 1 & 1 & 1 & 1 & 1 & 1 & 1 & 1 & 1 \\
\hline 163 & 1 & 1 & 1 & 1 & 1 & 1 & 1 & 1 & 1 & 1 & $\theta$ \\
\hline 104 & 1 & 1 & 1 & 1 & 1 & 1 & 1 & 1 & 1 & 1 & $\emptyset$ \\
\hline 105 & 1 & 1 & 1 & 1 & 1 & 1 & 1 & 1 & 1 & 1 & $\emptyset$ \\
\hline 166 & 1 & 1 & 1 & 1 & 1 & 1 & 1 & 1 & 1 & 1 & 0 \\
\hline 107 & 2 & 2 & 2 & 2 & 2 & 2 & 2 & 1 & 1 & 1 & 7 \\
\hline 108 & 1 & 1 & 1 & 1 & 1 & 1 & 1 & 1 & 1 & 1 & $\emptyset$ \\
\hline 109 & 1 & 1 & 1 & 1 & 2 & 1 & 2 & 1 & 1 & 1 & 2 \\
\hline 110 & 1 & 1 & 1 & 1 & 2 & 1 & 1 & 1 & 1 & 1 & 1 \\
\hline
\end{tabular}


付表1. 各パネルの回答結果 (1 良, 2 : 不良)

(2)

\begin{tabular}{|c|c|c|c|c|c|c|c|c|c|c|c|}
\hline 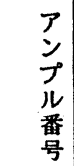 & $\begin{array}{l}ハ 2 \\
\text { ネ } \\
\text { I } \\
\mathrm{I}\end{array}$ & $\begin{array}{l}\text { パ } \\
\text { ホ } \\
\text { III }\end{array}$ & $\begin{array}{l}ハ ゚ \\
\text { ג } \\
\text { ルIII }\end{array}$ & $\begin{array}{l}\text { パ } \\
\text { ネ } \\
\mathbb{N}\end{array}$ & $\begin{array}{l}\text { パ } \\
\text { ג } \\
\text { V }\end{array}$ & $\begin{array}{l}\text { パ } \\
\text { 衤 } \\
\text { VI }\end{array}$ &  & 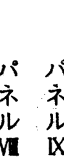 & 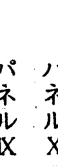 & $\begin{array}{l}\stackrel{1}{a} \\
\vdots \\
x\end{array}$ & \\
\hline 111 & 1 & 1 & 1 & 1 & 1 & 1 & 1 & 11 & 1 & & \\
\hline 112 & & 2 & 1 & & 2 & 1 & 1 & & & & \\
\hline 113 & & & & & & & & & 1 & & \\
\hline 114 & & & & & & & & & & & \\
\hline 115 & & & & & & & & & & & \\
\hline 16 & & 1 & & & & & & & & & \\
\hline $11 ?$ & & 1 & 1 & 1 & 2 & & & & & & \\
\hline 118 & & 2 & 1 & 1 & 2 & 2 & 2 & $i$ & 1 & & \\
\hline 19 & & 1 & 1 & 1 & 1 & 1 & 1 & 1 & 1 & & \\
\hline 2 & & 2 & 1 & 2 & 2 & 2 & 6 & 2 & 2 & 2 & \\
\hline 12 & & 2 & 1 & & & 2 & 2 & 1 & 2 & & \\
\hline 122 & & 1 & 1 & 1 & 2 & 1 & 2 & & & & \\
\hline 123 & & 2 & 1 & 1 & 2 & 1 & 1 & & & & \\
\hline 124 & & 1 & 1 & 2 & 2 & 1 & 1 & & & & \\
\hline 125 & & 2 & 1 & 1 & 2 & 2 & 1 & 1 & 1 & & \\
\hline 126 & & 1 & 1 & 1 & 1 & 1 & 1 & 1 & 1 & & \\
\hline 127 & 2 & 2 & 1 & 1 & 2 & 1 & 1 & 1 & 2 & & \\
\hline 128 & & 1 & 1 & 1 & 1 & 1 & 1 & 1 & 1 & & \\
\hline 129 & & 2 & 1 & 1 & 2 & $i$ & 1 & 2 & & & \\
\hline 13 & & 2 & & & 2 & 2 & & 2 & 2 & & \\
\hline & & & & & 1 & 1 & & & & & \\
\hline 132 & & $i$ & $i$ & $i$ & 2 & 1 & 2 & & & & \\
\hline 133 & 1 & 1 & 2 & 2 & 2 & 1 & 2 & 2 & 1 & & \\
\hline 134 & 1 & 2 & 1 & 2 & 2 & 2 & 2 & 2 & 2 & & \\
\hline 135 & & 1 & 1 & 1 & 2 & 2 & 2 & 1 & 1 & & \\
\hline 136 & & 1 & 1 & 1 & 1 & 1 & 1 & 1 & 1 & & \\
\hline 137 & & 1 & 2 & 2 & 2 & 1 & 1 & 1 & 1 & & \\
\hline 138 & 2 & 2 & 1 & 2 & 2 & 2 & 1 & 1 & & & \\
\hline 139 & & 1 & 1 & 1 & 1 & 2 & 1 & & & & \\
\hline 140 & & 2 &  & 1 & 2 & & 2 & & & & \\
\hline 14 & &  & 1 & 1 & 2 & 0 & & & & & \\
\hline 14 & 1 & 1 & 1 & 2 & 2 & 2 & & ? & & & \\
\hline 143 & 2 & 2 & 2 & 2 & 2 & 1 & 2 & $i$ & & & \\
\hline 144 & 1 & 1 & 1 & 1 & 1 & 1 & 1 & 1 & 1 & 1 & \\
\hline 145 & 1 & 2 & 1 & 1 & 2 & 1 & 2 & 2 & 1 & & 5 \\
\hline 146 & & 1 & 1 & 1 & 1 & 1 & 1 & 1 & 1 & & $\emptyset$ \\
\hline 147 & & 1 & 1 & 1 & 1 & 2 & 1 & 1 & & & 1 \\
\hline 148 & & 2 & 2 & 2 & 2 & 2 & & 2 & 2 & & \\
\hline 149 & & 2 & 2 & 2 & 2 & 2 & 2 & 2 & 2 & & 9 \\
\hline 15 & 1 & 1 &  &  & 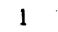 & & & 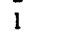 &  & & $\emptyset$ \\
\hline 15 & & 2 & 1 & 1 & 2 & 1 & 2 & 1 & & & \\
\hline & 1 & 1 & 1 & 1 & 1 & 1 & 1 & $i$ & i & & \\
\hline 15 & 1 & 2 & 1 & 1 & 1 & 1 & 1 & 1 & 1 & & 1 \\
\hline 15 & 2 & 1 & 2 & 1 & 2 & 1 & 1 & 1 & 2 & & 4 \\
\hline 15 & 2 & 2 & 2 & 1 & 2 & 2 & 2 & 2 & 2 & & 9 \\
\hline 15 & & 1 & 1 & 1 & 2 & 2 & & 1 & 1 & 2 & 3 \\
\hline 15 & 2 & 2 & 1 & 2 & 2 & 2 & 2 & 1 & 2 & & 7 \\
\hline 158 & 1 & 1 & 1 & 1 & 1 & 1 & & 1 & & & a \\
\hline 159 & 2 & 2 & & $?$ & & 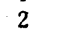 & 2 & ; & 2 & 2 & . \\
\hline 160 & 1 & 2 & & & & & & & & & \\
\hline & 1 & 1 & & & & & & & & & \\
\hline & 2 & 1 & 2 & 2 & 2 & 2 & 2 & 2 & 2 & & \\
\hline 163 & 2 & 2 & 2 & 2 & 2 & 2 & 2 & 2 & 2 & & 10 \\
\hline 164 & 1 & 1 & 1 & 1 & 1 & 1 & 1 & 1 & 1 & & $\theta$ \\
\hline 165 & & & 1 & & & 2 & & 1 & & & \\
\hline
\end{tabular}

\begin{tabular}{|c|c|c|c|c|c|c|c|c|c|c|c|}
\hline $\begin{array}{l}? \\
3 \\
\mathcal{3} \\
\text { U } \\
\text { 番 } \\
\text { 号 }\end{array}$ & $\begin{array}{l}\text { パ } \\
\text { 永 } \\
\text { I }\end{array}$ & $\begin{array}{l}\text { ハ } \\
\text { ル } \\
\text { II }\end{array}$ & $\begin{array}{l}\text { ハ } \\
\text { ネ } \\
\text { 吕 }\end{array}$ & $\begin{array}{l}\text { パ } \\
\text { ネ } \\
\text { 隹 }\end{array}$ & $\begin{array}{l}\text { パ } \\
\text { ネ } \\
\text { ル }\end{array}$ & $\begin{array}{l}ハ 2 \\
\text { ネ } \\
\text { VI }\end{array}$ & $\begin{array}{l}\stackrel{2}{\lambda} \\
\Re \\
\text { VII }\end{array}$ & $\begin{array}{l}ハ ゚ \\
\text { ネ } \\
\text { U }\end{array}$ & $\begin{array}{l}ハ ゚ \\
\text { ネ } \\
\text { ル }\end{array}$ & $\begin{array}{l}\text { パ } \\
\text { ネ } \\
\text { } \\
\mathrm{X}\end{array}$ & $\begin{array}{l}\text { 良 } \\
\text { 䈶 } \\
\text { 数 }\end{array}$ \\
\hline 66 & 1 & & & & 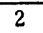 & 2 & 1 & & & & \\
\hline & & & & & 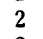 & & & & & 2 & \\
\hline & 2 & 2 & 2 & 1 & 2 & 2 & 2 & 2 & & 2 & \\
\hline & & & & 2 & 2 & 2 & 2 & & & & \\
\hline & & & & & 1 & 1 & & & & & \\
\hline & & & & & 2 & 1 & & & & & \\
\hline & & & & & 2 & 2 & 2 & & & & \\
\hline & $i$ & & & & 1 & 1 & 1 & & & & \\
\hline & & & 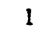 & 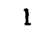 & $i$ & $i$ & $i$ & 1 & i & 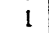 & \\
\hline & & & & & & & & 0 & & & \\
\hline & 1 & & & 1 & 1 & & & & & & \\
\hline & $i$ & 1 & & & 1 & & & & & & \\
\hline & 1 & 1 & 1 & 1 & $i$ & 1 & 1 & 1 & & & \\
\hline & 1 & 1 & 1 & 1 & 1 & 1 & 1 & 1 & & & \\
\hline & 1 & 1 & & & 1 & 1 & 1 & 1 & & & \\
\hline & 2 & 2 & 2 & & 2 & $?$ & 2 & 2 & & 2 & \\
\hline & 1 & & & & 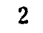 & 1 & 1. & 1 & & 1 & \\
\hline 8. & 1 & 1 & & & , & 2 & 1 & 1 & & & \\
\hline & 2 & 2 & & & 2 & 2 & 2 & 2 & & & \\
\hline & & & & & & 1 & 1 & 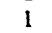 & & & \\
\hline & 1 & & & & & & & & & & \\
\hline & 2 & & & & & & & & & & \\
\hline & & & & & & & 1 & & & & \\
\hline & 2 & 2 & $i$ & & & 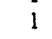 & $i$ & & & & \\
\hline & 1 &  & 1 & & 2 & 2 & 2 & 2 & 1 & & \\
\hline & 1 & 1 & & & 1 & 1 & 1 & 1 & & & \\
\hline & & & & & & 1 & 1 & 1 & & & \\
\hline & & & & & & 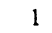 & 2 & & & & \\
\hline & & & & & & 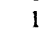 & & 2 & & & \\
\hline & & & & & & & & & & & \\
\hline & & & & & & & & & & & \\
\hline & & & & & & & & & & & \\
\hline &  & & & & & & & & & & \\
\hline & 1 & 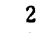 & 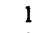 & 2 & 2 & 2 & 2 & & & & \\
\hline & 1 & 1 & 8 & 1 & 1 & 1 & 1 & 1 & 1 & & \\
\hline & & & 1 & & 1 & 1 & 1 & 1 & & & \\
\hline & & & 6 & & 1 & 1 & 1 & 1 & & & \\
\hline & & 1 & & & & & 1 & & & & \\
\hline & 1 & 1 & 1 & & & I & 1 & & & & \\
\hline & & & & & & 1 & $?$ & & & & \\
\hline & & & & & & & & & & & \\
\hline & & & & & & & & & & & \\
\hline & 1 & & 1 & & & 2 & 2 & & & & \\
\hline & & & 1 & 1 & 1 & 1 & 1 & & & & \\
\hline & 1 & 2 & 1 & $?$ & 2 & 1 & 2 & 2 & & & \\
\hline & & 1 & 1 & & 2 & 1 & 1 & 1 & & & \\
\hline & & 1 & 1 & & & & 1 & 1 & & & \\
\hline & & & & & & 2 & 1 & & & $?$ & \\
\hline & & & & & & & & & & & \\
\hline & & & & & & & & & & & \\
\hline & & & & & & & & & & & \\
\hline
\end{tabular}


付表 2. 各アンプルのカテゴリーデータ(1)

\begin{tabular}{|c|c|c|c|c|c|c|c|c|c|c|}
\hline 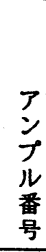 & 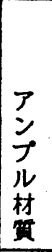 &  & 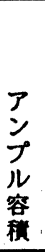 & 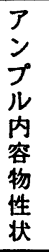 &  & $\begin{array}{l}\text { 印 } \\
\text { 殿 } \\
\text { 式 }\end{array}$ & $\begin{array}{l}\text { 即 } \\
\text { 色 } \\
\text { 数 }\end{array}$ & $\begin{array}{l}\text { 印 } \\
\text { 字 } \\
\text { 向 } \\
\text { 等 }\end{array}$ & $\begin{array}{l}\text { 識 } \\
\text { 别 } \\
\text { 年 } \\
\text { n }\end{array}$ & 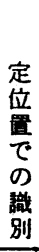 \\
\hline 1 & 1 & 1 & 5 & 1 & 1 & 1 & 1 & 2 & 1 & 2 \\
\hline 2 & 2 & 1 & 5 & 1 & 1 & 2 & 2 & 3 & & \\
\hline & 2 & & 5 & 1 & 1 & 2 & 2 & 3 & & \\
\hline & 1 & & 3 & 1 & 1 & 2 & 2 & 2 & 2 & 2 \\
\hline & 1 & & 5 & 1 & 1 & 1 & 1 & 2 & 1 & 2 \\
\hline & 1 & 1 & 1 & 3 & 1 & 1 & 1 & 2 & $i$ & 2 \\
\hline & 1 & 1 & 1 & 1 & 1 & 2 & 2 & 2 &  & 2 \\
\hline & 1 & 1 & 1 & 1 & 1 & 2 & 2 & 2 & 1 & 2 \\
\hline & 1 & 1 & 1 & 1 & 1 & 2 & & 2 & & 2 \\
\hline 10 & 1 & 1 & $\frac{1}{5}$ & 1 & 1 & 2 & 3 & & & 2 \\
\hline & 2 & 1 & 5 & 1 & 1 & 2 & 1 & 3 & 1 & 1 \\
\hline 12 & 2 & 1 & 5 & 1 & 1 & 2 & 2 & 3 & 1 & 1 \\
\hline 13 & 1 & 1 & 1 & 1 & 1 & 1 & 2 & 2 & 2 & 2 \\
\hline 14 & 1 & 1 & 3 & 2 & 1 & 1 & 1 & 2 & 1 & 2 \\
\hline 15 & 1 & 1 & 1 & 1 & 1 & 2 & 3 & 2 & 1 & 2 \\
\hline 16 & 1 & 1 & 3 & 3 & 1 & 1 & 3 & 2 & 1 & 1 \\
\hline 17 & 1 & 1 & 4 & 1 & 1 & 1 & 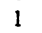 & 2 & ; & $i$ \\
\hline 18 & 1 & 2 & 3 & 1 & 1 & 2 & 3 & 2 & 1 & 2 \\
\hline 19 & 1 & 1 & 1 & 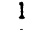 & 1 & 2 & 2 & & 2 & 2 \\
\hline 20 & 1 & 1 & 1 & 1 & 1 & 2 & 1 & 2 & 2 & 2 \\
\hline 21 & 1 & 1 & 2 & 1 & 1 & 1 & 1 & 2 & 1 & 2 \\
\hline 22 & 1 & 2 & 1 & 1 & 2 & 1 & 1 & 2 & 1 & 1 \\
\hline 23 & 1 & 1 & 1 & 1 & 1 & 1 & 1 & 2 & 1 & 1 \\
\hline 24 & 1 & 1 & 1 & 1 & 1 & 1 & 1 & 2 & 1 & 1 \\
\hline 25 & 1 & 1 & 5 & 1 & 2 & 1 & 1 & 2 & 1 & 2 \\
\hline 26 & 1 & 1 & 3 & 1 & 2 & 2 & 3 & 2 & & 2 \\
\hline 27 & 1 & 1 & 4 & 1 & 2 & 1 & 1 & 2 & & 1 \\
\hline 28 & 1 & 1 & 2 & 1 & 1 & & & & & 2 \\
\hline 29 & & 1 & 2 & 3 & 1 & 2 & & & 2 & 2 \\
\hline & & 2 & 1 & 1 & 1 & & & 2 & & 2 \\
\hline 31 & 1 & 1 & 2 & 1 & 1 & 4 & 3 & 2 & 1 & 2 \\
\hline 32 & 1 & 2 & 2 & ; & 1 & 1 & 1 & 2 & 1 & 1 \\
\hline 33 & 1 & 2 & 4 & 1 & 1 & 1 & 1 & 2 & 1 & 1 \\
\hline 34 & 1 & 2 & 5 & 1 & 1 & 1 & 1 & 2 & 1 & 1 \\
\hline 35 & 1 & 1 & 3 & 1 & 1 & 3 & 2 & 1 & 1 & 2 \\
\hline 36 & 1 & 1 & 3 & 1 & 1 & 2 & 3 & 2 & 1 & 2 \\
\hline 37 & 1 & 1 & 4 & 1 & 1 & 1 & & & 1 & 1 \\
\hline 38 & & 1 & 1 & 1 & 1 & 3 & 2 & & & 2 \\
\hline 39 & 1 & 2 & 1 & 1 & 1 & 1 & 2 & 2 & 1 & 2 \\
\hline 46 & 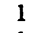 & 1 & 5 & 1 & 1 & 1 & 1 & 2 & & 2 \\
\hline 41 & 1 & 1 & 2 & 1 & 1 & 4 & 3 & 2 & 1 & 1 \\
\hline 42 & 1 & 1 & 2 & 2 & 1 & 2 & 3 & 1 & 1 & 2 \\
\hline 43 & 1 & 1 & 5 & 2 & 2 & 1 & 1 & 2 & 1 & 2 \\
\hline 44 & 1 & 1 & 3 & 1 & 1 & 2 & 3 & 2 & 1 & 2 \\
\hline 45 & 1 & 1 & 1 & 1 & 1 & 1 & 1 & 2 & 1 & 1 \\
\hline 46 & & 2 & 3 & 1 & 2 & 1 & 1 & 2 & 1 & 1 \\
\hline 47 & 1 & 2 & 2 & 1 & 1 & 2 & 2 & 1 & 1 & 2 \\
\hline 48 & 1 & 1 & 3 & 1 & 1 & 2 & 1 & 2 & 1 & 2 \\
\hline 49 & & 1 & 5 & & 1 & & & 2 & 1 & 2 \\
\hline 58 & & 2 & 2 & & 1 & 4 & & 2 & & 2 \\
\hline 51 & & 1 & 1 & & 1 & 2 & 3 & 2 & 1 & 2 \\
\hline 52 & & 2 & 1 & & 1 & 4 & 2 & & 1 & 2 \\
\hline 53 & & & 2 & 1 & 2 & 2 & 2 & 2 & 1 & 2 \\
\hline 54 & 1 & 1 & 2 & 3 & 1 & 1 & & & & \\
\hline & & & & & & & & & & \\
\hline
\end{tabular}

\begin{tabular}{|c|c|c|c|c|c|c|c|c|c|c|}
\hline $\begin{array}{l}3 \\
\mathcal{3} \\
\text { 番 } \\
\end{array}$ & 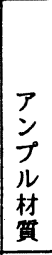 & 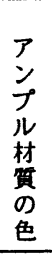 & 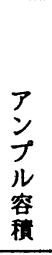 &  & 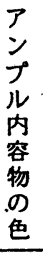 & $\begin{array}{l}\text { 即 } \\
\text { 乫 } \\
\text { 式 }\end{array}$ & $\begin{array}{l}\text { 即 } \\
\text { 刷 } \\
\text { 數 }\end{array}$ & $\begin{array}{l}\text { 印 } \\
\text { 字 } \\
\text { 向 }\end{array}$ & 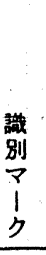 & $\begin{array}{l}\text { 定 } \\
\text { 熏 } \\
\text { て } \\
\text { の } \\
\text { 壪 } \\
\text { 别 } \\
\end{array}$ \\
\hline 56 & 1 & 1 & 1 & 1 & 1 & 1 & 2 & 2 & 1 & 1 \\
\hline 57 & & 1 & 1 & 1 &  & 2 & 2 & 2 & 1 & 2 \\
\hline 58 & & 2 & 1 & 1 & 1 & 1 & 1 & 2 & 1 & 1 \\
\hline 59 & & 1 & 3 & 1 & 1 & 2 & 3 & 2 & 1 & 2 \\
\hline 60 & & 2 & 2 & 1 & 1 & 1 & 1 & 2 & 2 & 1 \\
\hline 61 & 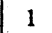 & 2 & 1 & 1 & 2 & 4 & 2 & 2 & 1 & 2 \\
\hline 62 & I & 1 & 3 & 3 & 1 & 1 & 1 & 2 & 1 & 2 \\
\hline 63 & & $?$ & $?$ & 3 & 1 & 3 & 2 & 1 & 1 & 2 \\
\hline 64 & & 1 & 4 & 1 & 1 & 2 & 2 & 1 & 1 & 2 \\
\hline 65 & & 1 & 3 & 1 & i & 2 & 2 & 2 & 1 & 2 \\
\hline & & 1 & 3 & 1 & 1 & 2 & 2 & 2 & 1 & \\
\hline 67 & & 1 & 4 & 1 & 1 & 2 & 4 & 2 & 1 & 2 \\
\hline 68 & & 1 & 2 & 1 & 1 & 2 & 4 & 2 & 1 & 2 \\
\hline 69 & & 1 & 5 & 1 & 1 & 1 & 1 & 2 & 1 & \\
\hline 70 & & 2 & 1 & 1 & 1 & 2 & 2 & 1 & 1 & 2 \\
\hline 71 & & 1 & 1 & 1 & 1 & 2 & 4 & 1 & 1 & 2 \\
\hline 72 & & 1 & 2 & 1 & 1 & 2 & 4 & 1 & 1 & 2 \\
\hline 73 & & 1 & 2 & 3 & 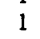 & 1 & 2 & 2 & 2 & 2 \\
\hline 74 & & 1 & 5 &  & 1 & 2 & 3 & 3 & 1 & 2 \\
\hline & & 1 & 5 & 1 & 1 & 2 & 3 & 3 & 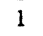 & \\
\hline 76 & 1 & 1 & 5 & 1 & 1 & 2 & 4 & 3 & 1 & 2 \\
\hline 77 & 1 & 1 & 5 & 1 & 1 & 2 & 3 & 3 & 1 & 2 \\
\hline 78 & 1 & 1 & 5 & 1 & 1 & 2 & 3 & 3 & 1 & 2 \\
\hline 79 & & 1 & 5 & 1 & 1 & 2 & 3 & 3 & 1 & 2 \\
\hline 80 & & 1 & 5 & 1 & 1 & 2 & 3 & 3 & 1 & 2 \\
\hline 81 & & 2 & 2 & 1 & 1 & 4 & 2 & 2 & 1 & 2 \\
\hline 82 & & 2 & 3 & 1 & 1 & 4 & 2 & 2 & 1 & 2 \\
\hline 83 & & 1 & 1 & 1 & 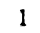 & 4 & 4 & 2 & 1 & 2 \\
\hline 84 & & 1 & 2 & & 1 & 4 & 4 & 2 & 1 & 2 \\
\hline & & 1 & 2 & 1 & & 2 & 2 & 2 & 1 & 2 \\
\hline & & 2 & 1 & 1 & 1 & 2 & 3 & 2 & 1 & \\
\hline & & 2 & 1 & 1 & 1 & 2 & 2 & 2 & 1 & \\
\hline 8 & 1 & 1 & 2 & 1 & 1 & 2 & 2 & 2 & 2 & 2 \\
\hline 8 & 1 & 2 & 1 & 1 & 1 & 2 & 2 & 2 & 1 & 2 \\
\hline $9 \emptyset$ & 1 & 1 & 1 & 1 & 1 & 2 & 3 & 2 & 1 & 2 \\
\hline 91 & & 1 & 2 & 1 & 1 & 3 & 3 & 2 & 1 & 2 \\
\hline & & & 2 & 3 & 1 & 2 & 1 & 1 & & 2 \\
\hline 93 & 1 & 2 & 2 & 1 & 1 & 1 & 1 & 2 & 1 & 1 \\
\hline 9 & & 2 & 1 & 1 & & 2 & 2 & 2 & 1 & 2 \\
\hline & 1 & 1 & 1 & 1 & & 4 & 4 & 2 & 1 & \\
\hline $9 \xi$ & 1 & 1 & 2 & 1 & & 2 & 3 & 1 & 1 & \\
\hline 97 & 1 & 2 & 2 & 1 & 1 & 2 & 1 & 1 & 1 & 2 \\
\hline 98 & 1 & 1 & 3 & 3 & 1 & 2 & 3 & 2 & 1 & 2 \\
\hline 99 & & 1 & 2 & 1 & 1 & 2 & 1 & 2 & 2 & 2 \\
\hline 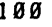 & 1 & 1 & 2 & 3 & 1 & 1 & 1 & 2 & 1 & 2 \\
\hline & 1 & 1 & 2 & & 1 & 2 & 3 & 1 & 2 & 2 \\
\hline 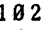 & 1 & 1 & 3 & & & 2 & 3 & 1 & 2 & 2 \\
\hline 03 & 1 & 2 & 1 & & & 2 & 2 & 2 & 1 & 2 \\
\hline 184 & 1 & 2 & 3 & & & 2 & 1 & 2 & & 2 \\
\hline 65 & 1 & 1 & 2 & & & 2 & 2 & & & \\
\hline 106 & 1 & 1 & 3 & 1 & & 2 & 2 & 2 & $1:$ & \\
\hline 18 & 1 & 1 & 1 & 1 & & 1 & 1 & 2 & 1 & \\
\hline 108 & 1 & 1 & 1 & 1 & 1 & 2 & 3 & 2 & 1 & 2 \\
\hline 109 & 1 & 1 & 4 & 1 & 1 & 1 & 2 & 2 & 1 & 1 \\
\hline 18 & & & & & & & & & & 2 \\
\hline
\end{tabular}


付表 2. 各アンプルのカテゴリーデータ(2)

\begin{tabular}{|c|c|c|c|c|c|c|c|c|c|c|}
\hline $\begin{array}{l}\text { P } \\
\text { フ } \\
\text { ル } \\
\text { ル } \\
\text { 番 } \\
\text { 易 }\end{array}$ & $\begin{array}{l}\text { ア } \\
\text { ン } \\
\text { プ } \\
\text { U } \\
\text { 材 } \\
\text { 筫 }\end{array}$ & 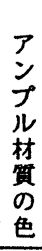 & $\begin{array}{l}\text { ア } \\
\text { ว } \\
\text { プ } \\
\text { ル } \\
\text { 容 } \\
\text { 種 }\end{array}$ & $\begin{array}{l}\text { ア } \\
\text { ב } \\
\text { プ } \\
\text { 内 } \\
\text { 内容 } \\
\text { 物 } \\
\text { 性 } \\
\text { 状 }\end{array}$ & 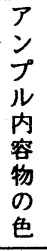 & $\begin{array}{l}\text { 印 } \\
\text { 刷 } \\
\text { 方 } \\
\text { 式 }\end{array}$ & $\begin{array}{l}\text { 印 } \\
\text { 殿 } \\
\text { 色 } \\
\text { 数 }\end{array}$ & $\begin{array}{l}\text { 印 } \\
\text { 字 } \\
\text { 方 } \\
\text { 向 }\end{array}$ &  & 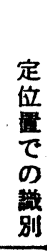 \\
\hline 11 & 1 & 1 & 3 & 1 & 1 & $?$ & 3 & 2 & 1 & 2 \\
\hline & & 1 &  & 1 & & & & & & \\
\hline & & 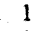 & 1 & 1 & & & 1 & 2 & & \\
\hline & 1 & 1 & 3 & 2 & 1 & 1 & 1 & 2 & 1 & \\
\hline 15 & 1 & 2 & 1 & 1 & & & ? & & & \\
\hline 1 & & 1 & 2 & 1 & & & & & & \\
\hline 17 & 1 & 1 & 2 & 1 & 1 & 1 & 1 & 2 & & \\
\hline 11 & & 1 & 4 & 1 & 1 & & & & & \\
\hline 11 & 1 & 1 & 4 & 1 & 1 & 2 & 2 & 2 & 1 & \\
\hline 12 & 1 & 1 & 3 & 2 & 1 & & & & & \\
\hline 12 & & 1 & 3 & 2 & 1 & & 1 & 2 & & \\
\hline 2 & & 1 & 1 & 1 & 1 & 1 & & & & \\
\hline 12 & & 1 & 4 & 1 & 1 & & & & & \\
\hline 12 & 1 & 2 & 1 & 1 & 1 & & & 2 & & \\
\hline 12 & 1 & & 5 & 1 & 1 & & & & & \\
\hline 12 & & 1 & 2 & 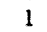 & & & & 2 & & \\
\hline 12 & 1 & 1 & 3 & 1 & 1 & & & 2 & & \\
\hline 12 & & 2 & 5 & 1 & & & & & & \\
\hline 12 & 1 & 1 & 1 & 1 & & & & & & \\
\hline 13 & 1 & 2 & 1 & 1 & 1 & & & & & \\
\hline 13 & & & 1 & 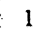 & & & & 2 & & \\
\hline 132 & 1 & 1 & 2 & 1 & 2 & & & & & \\
\hline 13 & 1 & 1 & 1 & 1 & & & & & & \\
\hline 13 & 1 & 1 & 1 & 1 & & 1 & 1 & 2 & 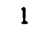 & \\
\hline 13 & 1 & 1 & 2 & 1 & 1 & 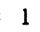 & 1 & 2 & & \\
\hline 13 & 1 & 1 & 2 & 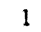 & 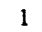 & 4 & 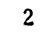 & 2 & & \\
\hline 13 & 1 & 1 & 2 &  & & & & & & \\
\hline 13 & 1 & 1 & 1 & 1 & & & & & & \\
\hline 1 & 1 & 1 & 1 & 1 & 1 & & & & & \\
\hline 14 & 1 & & 3 & 1 & 1 & & & & & \\
\hline & & 2 & 2 & 1 & 1 & & 1 & 1 & & \\
\hline & 1 & 1 & 1 & 1 & 1 & & & & & \\
\hline & & 1 & 2 & 1 & & & & & & 1 \\
\hline & & 2 & 3 & 1 & 1 & & & & 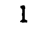 & 2 \\
\hline & & 2 & 1 & 1 & 1 & & & & & \\
\hline & & 1 & 1 & 1 & 1 & 6 & 1 & 8 & 2 & 2 \\
\hline & & 1 & 1 & 1 & 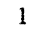 & & & & & 2 \\
\hline & & 2 & 1 & 1 & 1 & & & & & \\
\hline & 1 & 2 & 1 & 1 & 1 & 1 & 1 & 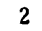 & 1 & 2 \\
\hline & & 1 & 2 & & & & & & & \\
\hline & 1 & 1 & 2 & 1 & 2 & & 1 & 2 & & 2 \\
\hline 15 & & 1 & , & & & 2 & & & 1 & 2 \\
\hline & & 1 & $?$ & 3 & 1 & & & & & \\
\hline & 1 & 1 & 2 & 1 & , & 1 & 2 & 2 & 1 & 1 \\
\hline & & 1 & 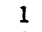 & 1 & & & & & & , \\
\hline & 1 & 1 & 1 & 1 & 2 & 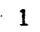 & 1 & 2 & 1 & 2 \\
\hline & & 1 & 3 & 1 & 2 & 3 & 1 & 1 & 1 & \\
\hline & & 1 & 5 & 1 & & & & 2 & & \\
\hline & 1 & 1 & 1 & 1 & 1 & 3 & 3 & 1 & 2 & 2 \\
\hline & 1 & , & 1 & 1 & & & 2 & 2 & & 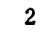 \\
\hline & 1 & 2 & 4 & 1 & 2 & 2 & 3 & 2 & & 2 \\
\hline & 1 & 1 & 1 & 1 & 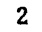 & 1 & 1 & 1 & 1 & 2 \\
\hline & & 1 & 1 & 1 & 2 & 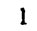 & 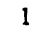 & 1 & & 2 \\
\hline & 1 & 2 & 2 & 1 & 1 & 2 & 1 & 2 & 1 & 2 \\
\hline & & 1 & 1 & 3 & & 2 & 2 & 2 & 1 & \\
\hline
\end{tabular}

\begin{tabular}{|c|c|c|c|c|c|c|c|c|c|c|}
\hline $\begin{array}{l}\text { ア } \\
\text { プ } \\
\text { ル } \\
\text { 番 } \\
\text { 号 }\end{array}$ & $\begin{array}{l}\text { ア } \\
\text { フ } \\
\text { プ } \\
\text { ル } \\
\text { 材 } \\
\text { 貿 }\end{array}$ & 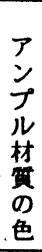 & $\begin{array}{l}\text { ア } \\
\text { ว } \\
\text { プ } \\
\text { ル } \\
\text { 容 } \\
\text { 䅡 }\end{array}$ & $\begin{array}{l}3 \\
\text { ב } \\
\text { プ } \\
\text { ル } \\
\text { 内 } \\
\text { 容 } \\
\text { 物 } \\
\text { 壮 }\end{array}$ & $\begin{array}{l}\text { 了 } \\
\text { 之 } \\
\text { J } \\
\text { 呙 } \\
\text { 容 } \\
\text { 物 } \\
\text { 色 }\end{array}$ & $\begin{array}{l}\text { 印 } \\
\text { 刷 } \\
\text { 方 } \\
\text { 式 }\end{array}$ & $\begin{array}{l}\text { 即 } \\
\text { 刷 } \\
\text { 急 } \\
\text { 数 }\end{array}$ & $\begin{array}{l}\text { 即 } \\
\text { 字 } \\
\text { 方 } \\
\text { 向 }\end{array}$ & 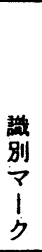 &  \\
\hline 166 & 1 & 1 & $?$ & 3 & 1 & 2 & 2 & 2 & 1 & \\
\hline & & & & & & & & & & \\
\hline & 1 & 1 & 1 & 1 & 1 & 1 & & 2 & 1 & \\
\hline & 1 & 1 & 1 & 1 & 1 & 1 & & 2 & 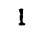 & \\
\hline 78 & 1 & & & 3 & 1 & 4 & & & & \\
\hline & 1 & 1 & 1 & 1 & 1 & 2 & 2 & 2 & 1 & \\
\hline 7 & 1 & 1 & 3 & 1 & 1 & & & & 1 & \\
\hline & 1 & & 3 & 3 & 1 & 2 & & 2 & 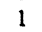 & \\
\hline & 1 & 1 & 3 & 3 & 1 & & & & 1 & \\
\hline 17 & 1 & & & 1 & 1 & & & & & \\
\hline & & & 2 & 1 & 2 & 3 & & & $?$ & \\
\hline 17 & 1 & 2 &  & 1 & 1 & & & & & \\
\hline & 1 & 2 & 2 & 1 & 1 & 4 & & &  & \\
\hline & 1 & 1 & 3 & 1 & , & 2 & & &  & \\
\hline 18 & 1 & 1 & 1 & 1 & 1 & & & & & \\
\hline & 1 & 1 & 1 & 1 & 2 & & & & & \\
\hline & 1 & 1 & 3 & 3 & 1 & & & & & \\
\hline 8 & 1 & 1 & 1 & 1 & 1 & & & & & \\
\hline & 1 & 1 & 1 & 1 & 1 & 1 & & & 1 & \\
\hline & 1 & 1 & 2 & 1 & 1 & 2 & & & 2 & \\
\hline & 1 & 2 & 4 & 1 & 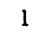 & & & & & \\
\hline & 1 & & & 1 & 1 & & & & & \\
\hline & 1 & 2 & & 1 & 1 & & & & & \\
\hline & 1 & 1 & 3 & 1 & 1 & & & & 2 & \\
\hline & 1 & 1 & 1 & 1 & 1 & & & & 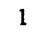 & \\
\hline & 1 & 1 & 1 & & 1 & & & & 1 & \\
\hline & 1 & & 1 & & 2 & & & & & \\
\hline & 1 & 1 & 2 & 1 & 1 & 4 & & & i & 1 \\
\hline & 1 & & & & 1 & & & & & \\
\hline & 1 & 1 & 1 & 1 & 1 & & & & & \\
\hline & 1 & 2 & 1 & & & & & & & \\
\hline & 1 & 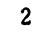 & 2 & 1 & 1 & & & & & \\
\hline & i & 2 & 4 & 1 & 1 & 2 & 3 & & 1 & 2 \\
\hline & & & & & & & & & & \\
\hline & 1 & 1 & 5 & & & & & & & \\
\hline & 1 & 1 & 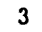 & 1 & & 2 & 4 & 1 & 1 & 2 \\
\hline & 1 & 1 & 4 & 1 & & & & & & \\
\hline & 1 & 1 & 1 & 1 & 2 & & & & 1 & \\
\hline & 1 & 1 & 1 & 1 & & & & & 1 & \\
\hline & 1 &  & 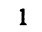 & 1 & & & & & & \\
\hline &  & 1 & 1 & 1 & 1 & & & & 1 & \\
\hline & 1 & & & 1 & & 2 & & & 1 & \\
\hline & 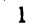 & 2 & 1 & 1 & 1 & & & & & \\
\hline & 1 & 1 & 1 & 1 & 1 & 2 & 1 & & 2 & \\
\hline & 1 &  & , & & & & & & & \\
\hline & 1 & 1 & 1 & 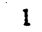 & 1 & 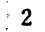 & 2 & & 1 & \\
\hline & 1 & & 1 & & & & & & 1 & \\
\hline & 1 & 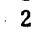 & 1 & & $i$ & & & & 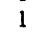 & 2 \\
\hline & 1 & 1 & 1 & 1 & 1 & 1 & & 2 & 1 & \\
\hline & , & 1 & 1 & 1 & 1 & & 3 &  & 1 & \\
\hline & 1 & 2 & 2 & 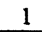 & & 2 & 2 & & & \\
\hline
\end{tabular}

